\title{
USING ANALYTICAL HIERARCHY PROCESS IN ARCGIS TO PREDICT LANDSLIDE HAZARD OF THUMBA BASIN, TAPLEJUNG.
}

\author{
Sakunda Ojha1, Shilpa Koirala² \\ ${ }^{1}$ Sanima Hydropower Ltd \\ email:sakunda@sanimahydro.com \\ ${ }^{2}$ Sanima Hydro and Engineering Pvt. Ltd \\ email: shilpa.koirala@sanimahydro.com.np
}

\begin{abstract}
Landslides have catastrophic impacts mainly on the rough terrain of hilly/ mountainous regions in Nepal. In this study, Landslide hazard of Thumba River basin located in Taplejung district of Nepal is predicted using Analytical Hierarchy Process (AHP) and Geographic Information System (GIS) tool. The major physical and ecological factors that are considered in landslide hazard mapping are; topographical heights to generate slope and aspect, land use pattern, drainage density, distance from streams and existing landslides. The weightage values to the factors are set using pairwise comparison matrix and standard matrix. Several landslide susceptible zones are delineated as High, Medium and Low by unequal interval classification method in ArcGIS. The final susceptibility map shows that about $60 \%$ of south facing cultivated land within the elevation range of $1700-2200 \mathrm{~m}$ amsl comprise $70 \%$ vulnerable hazard coverage on Thumba basin. The map was verified with existing landslide locations which yielded close proximity. Hence, any planners, decision-makers, concerned authorities can cogitate combined AHP and GIS application in landslide hazard mapping as required for various developmental projects.
\end{abstract}

Keywords: ArcGIS, AHP, Hazard, Thumba basin, Landslide

\section{INTRODUCTION}

Nepal is a mountainous country with varied topography, composite geological features, diverse climatic range and dense population. Human intervention on steep slopes along various topography has made the flat lands and hilly area susceptible to hazards such as floods and landslides. The frequency of occurrence of such calamities have been increasing during the recent years resulting in loss of millions of lives and properties. The impacts of the calamities are more prominent during monsoon period. Early prediction of such events and identification of hazard zones beforehand could save millions of life and properties. In this context, application of AHP method in Geographic Information System (GIS) tool could be appropriate in prediction of landslide hazard. GIS based AHP method has also been applied in previous studies which has proved to be very effective and valuable method to landslide susceptibility mapping (Ercanoglu et al., 2008; Yalcin, 2008). In the present study, various physical and ecological factors influencing the landslides have been considered for impact zonation. AHP method is used to provide weightage to the factors before processing in ArcGIS.

\section{MATERIALS AND METHODS}

Study Area: The study area lies in Mikwa Khola Rural Municipality (former Khoklin VDC) of Taplejung district of Eastern Development Region of Nepal. Geographically, the study area is located between longitude $87^{\circ} 40^{\prime} 24.108^{\prime \prime} \mathrm{E}$ and latitude $27^{\circ} 23^{\prime} 48.18^{\prime \prime} \mathrm{N}$ (confluence of the basin and Tamor River). The basin covers an area of $4.01 \mathrm{~km}^{2}$. Thumba Khola - one of the tributaries of Tamor Khola, basin extends from $3.45 \mathrm{~km}$ north to south and $1.98 \mathrm{~km}$ from east to west. The basin have a dendritic shape and extends within the elevation range of $760 \mathrm{~m}$ amsl 
to $2680 \mathrm{~m}$ amsl. The catchment includes three villages namely; Sanwa, Wairakhu and Subbagaun.

The basin lies in sub -tropical and temperate bio-climatic zone. The average yearly precipitation in the basin is $2561 \mathrm{~mm}$ (Ref: meteorological station no. 1404 located at Tapethok). Temperature varies from maximum $28.4{ }^{\circ} \mathrm{C}$ in the month of July to minimum 1.8 ${ }^{\circ} \mathrm{C}$ in the month of January (Ref: meteorological station no. 1405).

Geologically, the project area is located in Lesser Himalaya which is characterized by highly rugged relief with extremely varied topography.

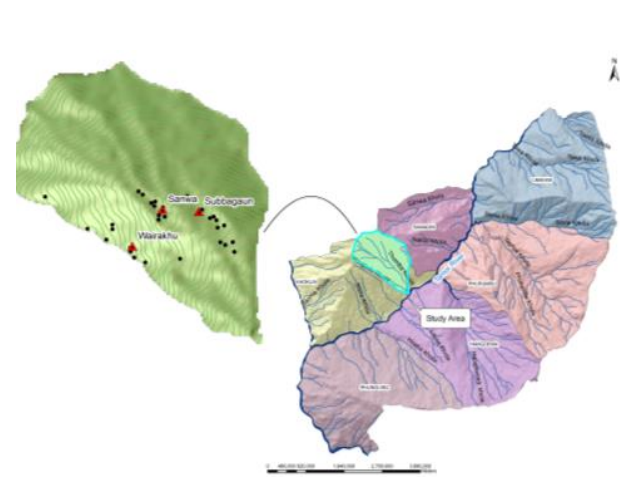

Figure 1: Study Area, Thumba Basin

About $47 \%$ land within the basin is cultivated and remaining is forest and river. The major settlement within the catchment is Sanwa village which consists 501 households with 1095 male and 1315 female population. Major population of the village belongs to Limbhu ethnic group.

Data Used: In this study, Primary data were produced through site investigation whereas, secondary data were generated using topographic map of Taplejung District; sheet no: 278711 and 2787 12. The topographic factors influencing the landslides such as slope, aspectand drainage density were acquired from the Digital Elevation Model (DEM). Other factors such as soil type and landuse were derived from digital information provided by GoN and FAO. Existing and past landslides were mapped through field investigation and Google Earth Image interpretation. All factors mentioned were co-related with past occurred event. For each attribute, data/ maps were integrated and numerically rated according Saaty Scale of Comparison, (Saaty 1980) .The data and sources utilized are mention in Table 1. ;

Table 1: Hazard mapping done through different data layers and its sources.

\begin{tabular}{|c|c|c|c|}
\hline Data layer & $\begin{array}{l}\text { GIS Data } \\
\text { Type }\end{array}$ & Sources & Scale \\
\hline Topographical Map & Polygon & $\begin{array}{c}\text { Department of survey (DoS), } \\
\text { Government of Nepal (GoN). } \\
\text { Topographical Map }\end{array}$ & $1: 25000$ \\
\hline $\begin{array}{l}\text { Slope, aspect and } \\
\text { drainage density } \\
\text { map }\end{array}$ & Raster & $\begin{array}{l}\text { DoS map, } \\
\text { Using Spatial Analyst Extension in } \\
\text { Arc GIS } 10 \text { and Aster (DEM) data. }\end{array}$ & $1: 16000$ \\
\hline Soil & Grid & $\begin{array}{l}\text { Field investigation and SOTER by } \\
\text { FAO }\end{array}$ & $1: 16000$ \\
\hline $\begin{array}{l}\text { Land use/land } \\
\text { cover mapping }\end{array}$ & Grid & $\begin{array}{l}\text { Digital LULC map, Image } \\
\text { classification tool in ArcGIS } 10 .\end{array}$ & $1: 16000$ \\
\hline Existing Landslide & Raster & $\begin{array}{c}\text { Field investigation and } \\
\text { Landsat/Copernicus. Google earth } \\
\text { Image (2017) }\end{array}$ & \\
\hline
\end{tabular}

\section{Data Layer}

\section{Slope}

Slope of Thumba catchment area was derived from the Digital Elevation Model (DEM). The slope was categorized into 5 classes at an interval of 45 degree. Generally, susceptibility of instability is high in the steeper slope as compared to the gentler. Gravity pull is also a 
governing factor for the instability. About $63 \%$ of the catchment consists of weathered rock area with slope ranging from 30 to 45 degree - which makes it vulnerable to land slide.

\section{Aspect}

Aspect was derived from the DEM and classified as flat, North, Northeast, South east, South west and West. During the field investigation, existing landslides were found higher in the south facing slopes. Aspect (slope orientation) affects the exposure to sun-light, wind and precipitation thereby indirectly affecting other factors that contribute to landslides such as soil moisture, vegetation cover and soil thickness. (Clerici. et al.2006).

\section{Elevation}

The elevation of the study area ranges from $760 \mathrm{~m}$ asl to $2680 \mathrm{~m}$ asl. The area is characterized by flat river terrace and debris flow along gullies and steep slopes. The elevation below 2000 $\mathrm{m}$ asl is considered as "Lesser Himalaya", Siwalik region. This region is prone to mass slide and debris flow in the Himalayan belt region. The study land area comprises of hollows and these regions usually slide materials and converge into the narrow region at the base of the slope. (Reneau and Dietrich 1987)

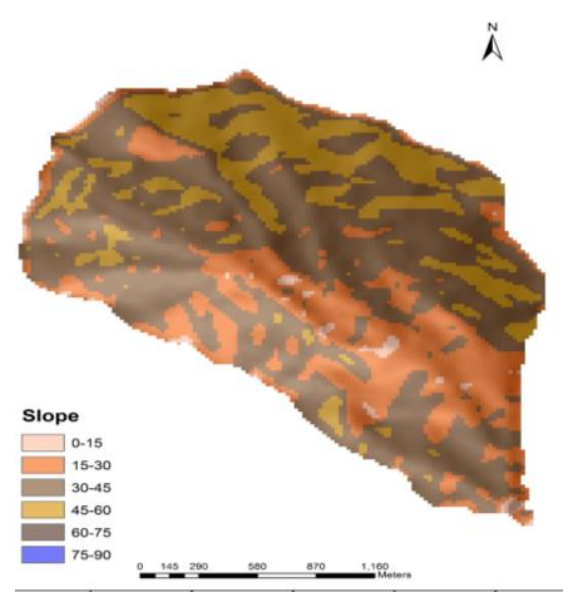

Figure 2: Slope map of the study area

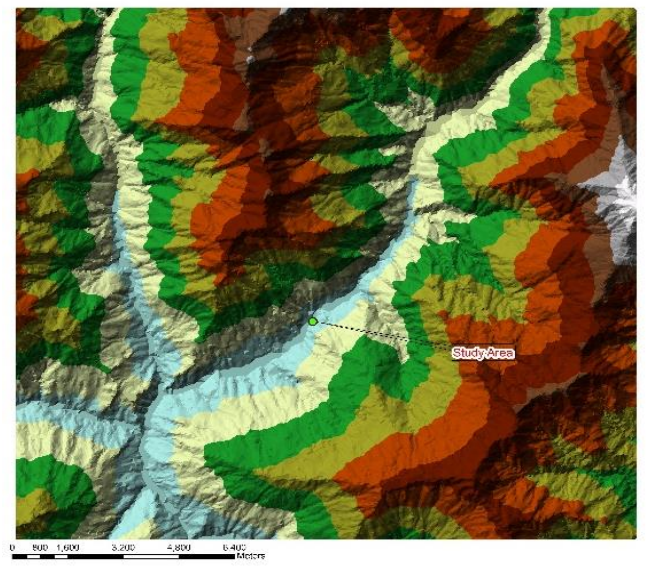

Figure 4: Elevation map of study area (TIN)

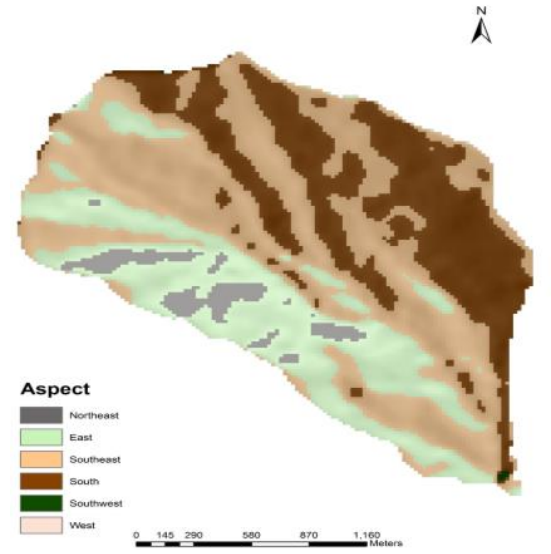

Figure 3: Aspect map of study area

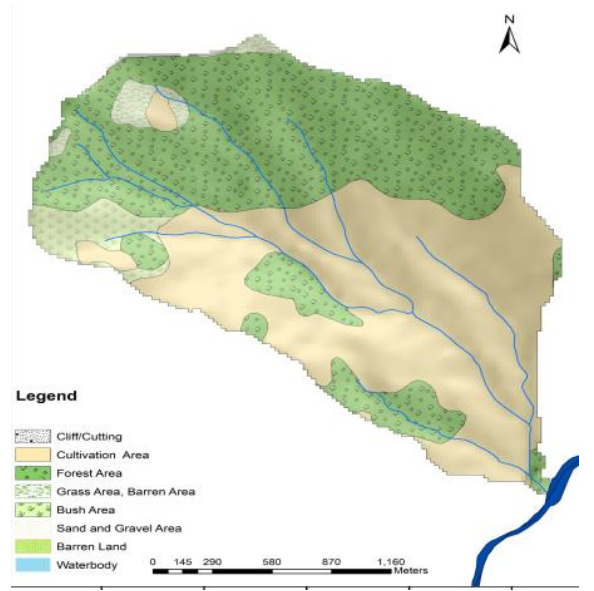

Figure 5: Land use map of Thumba basin 


\section{Land use}

For Land use map, DEM data and satellite image of Landsat/Copernicus derived from google earth (2016) was referred. The land use classes considered are; cultivated land, forest cover, bush land, barren land and water body. About $48 \%$ of the basin area consists of cultivation land (210.26 ha) which is followed by forest and bush land.

According to ICIMOD, the project area consists of Mixed Broad leaved Forest (10.241 ha) at an elevation range of 2400-2680 m amsl, East Himalayan Oak Laurel Forest (211.15 ha) at an elevation range of 2360-1640 m amsl, Schima Castanopsis Forest (204.12 ha) at an elevation range of 1600-1000 m amsl and Hill Sal Forest (13.520 ha) at the lower part of the study area.

5. Soil type

According to FAO, soil types are classified as; Humic Cambisols (CMu), Eutric Regosols (RGe) and Eutric Cambisols (CMe). Cambisols have high resilience to degradation, and moderate sensitivity to yield decline whereas, Regosols are characterized as weakly shallow formation soil, and medium- to fine-textured, unconsolidated parent material that may be of alluvial origin.

\section{Drainage}

It is dependent on climate, geology (bedrock), vegetation and concentration of rainfall. The confluence of Thumba Khola and its tributaries drifts from concave slope and water pressures are usually higher in those axial regions. Area having higher drainage density is usually prone to shallow-seated landslide whereas, large scale landslide is frequent in area having lesser drainage density (Hasegawa et al. (2008) during heavy rainfall. The yearly total precipitation record from the station number 1404 located at Tapethok is $2561 \mathrm{~mm}$; the total monsoon rainfall is $1979 \mathrm{~mm}$; maximum at month of July is $590 \mathrm{~mm}$; minimum monthly rainfall for October, November, and December is $0 \mathrm{~mm}$.

7. Distance from streams

The drainage density and its saturation degree plays a vital role in instability. It can erode the nearby slopes or saturates the lower part until water level rises. Thus, streams are offset and classified into five groups from 0-100 at the range of $20 \mathrm{~m}$ distance. Distance from rivers segments shows the proximity to potential paths of debris or sediment movement, and potential erosion location.

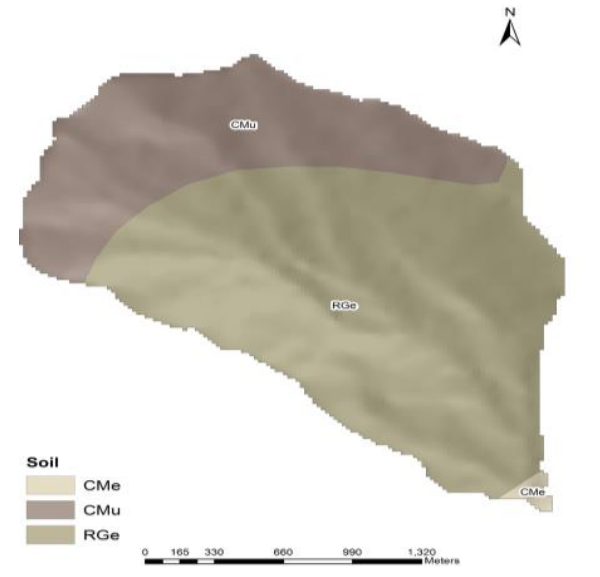

Figure 5: Soil type in the study Basin

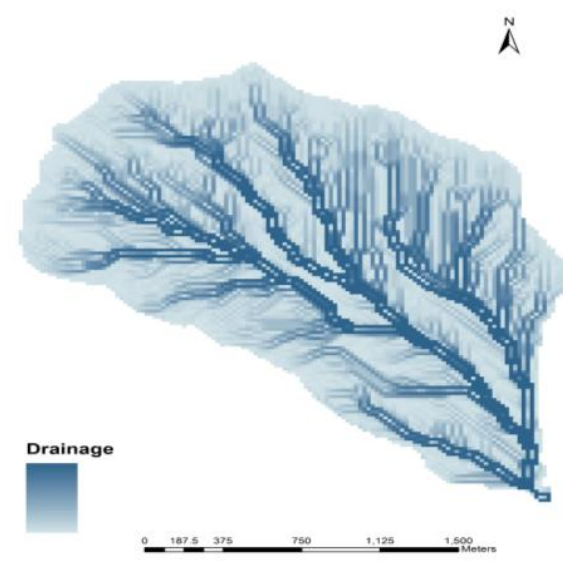

Figure 6: Drainage Density of study area.

\section{Existing Landslide}


Landscapes can be dramatically reshaped by landslides, with more gradual erosion process. The present landslide can lead to future landslides. The areas close to the existing landslides are more prone to landslides in the future. Scrutinizing the maps, Google earth image and site investigation (Figure 7), we can deduct that the past landslides have mostly been scattered in the south facing areas at the elevation range of 1500-2400 amsl.

AHP method: The Analytic Hierarchy Process (AHP) is a structural framework that enhances the realization of complicated decisions by decomposing the issue in a hierarchical structure. In the present study, a hierarchy of landslide causative factors are compared to each other in a matrix in which every factors are rated with other factor giving a score value. The scores are provided based on the comparative precedence of the factor introduced by Saaty (1977).

Table 2 and Table 3 shows the comparison matrix

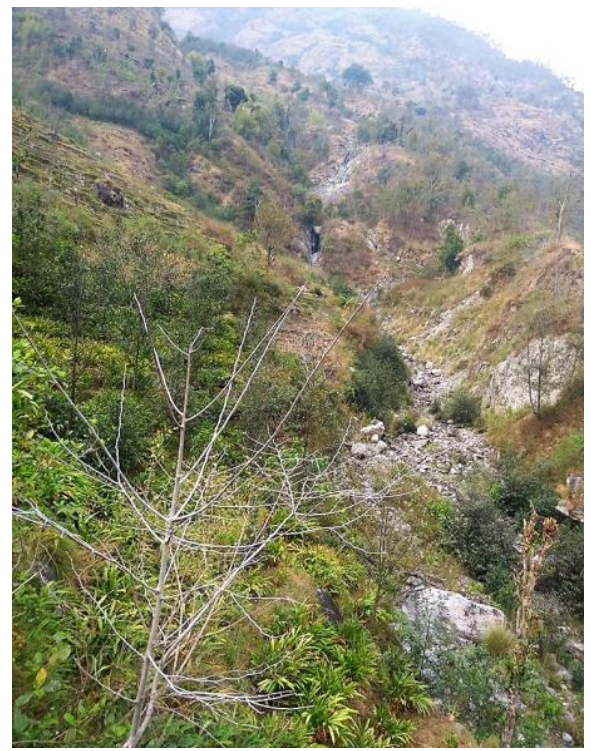

Figure 7: Existing Landslide in the Study Basin

between set factors and standardized matrix to derive the weighted percentage value.

Table 2 Pairwise Comparison Matrix:

\begin{tabular}{|c|c|c|c|c|c|c|c|c|}
\hline & $\begin{array}{c}\text { Slop } \\
e\end{array}$ & $\begin{array}{c}\text { Aspec } \\
t\end{array}$ & $\begin{array}{c}\text { Elevatio } \\
n\end{array}$ & $\begin{array}{l}\text { Soil } \\
\text { Type }\end{array}$ & $\begin{array}{c}\text { Land } \\
\text { use }\end{array}$ & $\begin{array}{c}\text { Drainag } \\
e \\
\text { Density }\end{array}$ & $\begin{array}{c}\text { Existing } \\
\text { Landslide } \\
s\end{array}$ & $\begin{array}{l}\text { Distanc } \\
\text { e From } \\
\text { Streams }\end{array}$ \\
\hline Slope & 1 & 5 & 3 & 3 & 4 & 5 & 1 & 5 \\
\hline Aspect & 0.2 & 1 & 5 & 3 & 7 & 4 & 9 & 2 \\
\hline Elevation & $\begin{array}{c}0.33 \\
3\end{array}$ & 0.2 & 1 & 4 & 2 & 3 & 2 & 1 \\
\hline Soil Type & $\begin{array}{c}0.33 \\
3\end{array}$ & 0.33 & 0.25 & 1 & 1 & 3 & 5 & 5 \\
\hline Land use & 0.25 & 0.14 & 0.5 & 1 & 1 & 4 & 1 & 3 \\
\hline $\begin{array}{c}\text { Drainage } \\
\text { Density }\end{array}$ & 0.2 & 0.25 & 0.33 & 0.33 & 0.25 & 1 & 5 & 2 \\
\hline $\begin{array}{c}\text { Existing } \\
\text { Landslide } \\
\quad s\end{array}$ & 1 & 0.11 & 0.5 & 0.2 & 0.2 & 0.2 & 1 & 5 \\
\hline $\begin{array}{l}\text { Distance } \\
\text { From } \\
\text { Streams }\end{array}$ & 0.2 & 0.5 & 1 & 0.2 & 0.5 & 0.5 & 0.2 & 1 \\
\hline
\end{tabular}

Table 3 Standardized Matrix

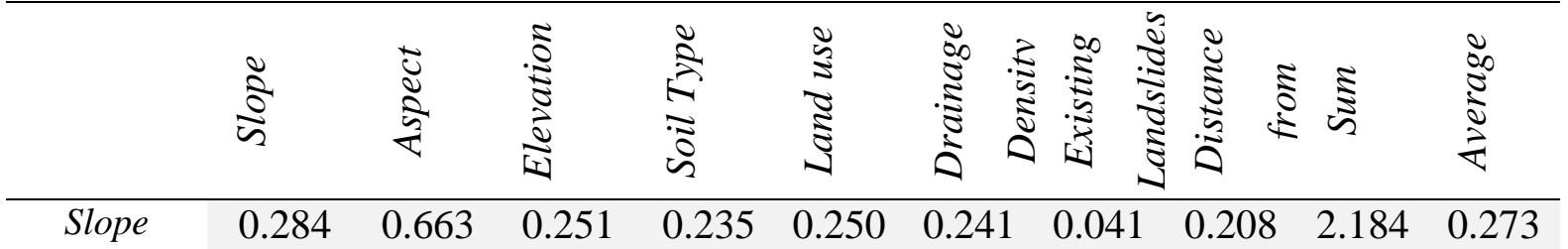




\begin{tabular}{|c|c|c|c|c|c|c|c|c|c|c|}
\hline Aspect & 0.056 & 0.132 & 0.438 & 0.235 & 0.438 & 0.193 & 0.371 & 0.083 & 1.944 & 0.243 \\
\hline Elevation & 0.904 & 0.026 & 0.086 & 0.314 & 0.125 & 0.144 & 0.082 & 0.041 & 0.916 & 0.114 \\
\hline Soil Type & 0.904 & 0.044 & 0.021 & 0.078 & 0.062 & 0.144 & 0.206 & 0.208 & 0.861 & 0.107 \\
\hline Landuse & 0.071 & 0.018 & 0.043 & 0.078 & 0.062 & 0.193 & 0.041 & 0.125 & 0.633 & 0.079 \\
\hline $\begin{array}{c}\text { Drainage } \\
\text { Density }\end{array}$ & 0.056 & 0.033 & 0.0287 & 0.026 & 0.015 & 0.048 & 0.206 & 0.083 & 0.498 & 0.062 \\
\hline $\begin{array}{c}\text { Existing } \\
\text { Landslides }\end{array}$ & 0.285 & 0.014 & 0.043 & 0.015 & 0.012 & 0.009 & 0.04 & 0.208 & 0.629 & 0.078 \\
\hline $\begin{array}{c}\text { Distance } \\
\text { from } \\
\text { Streams }\end{array}$ & 0.056 & 0.066 & 0.0863 & 0.015 & 0.031 & 0.024 & 0.008 & 0.041 & 0.330 & 0.04 \\
\hline
\end{tabular}

\section{Integration of AHP and GIS}

Weightage to factors; Each factors are given weightage values on percentage basis from 0100 - as derived from the standard comparison matrix (Table 4), to compute Landslide Potential Index . Pareta et. al, (2012) defines the Landslide Potential Index as:

\section{Landslide Potential Index $=\Sigma \mathrm{n} i=1(\mathrm{Ri} * \mathrm{Wi})$}

(1)

Where Ri denotes the rank for factor $\mathrm{i}$ and Wi denotes the weight of class of factor $\mathrm{i}$. In this study the total number of factors (n) is 8 , where weight of class varies from 0 to 5 .

Finally, with the completion of all the above mentioned steps Landslide Hazard Zonation (LHZ) Map was prepared. For better understanding and interpretation of the LHZ Map, the map was further analysed using the Zonal Histogram Function in the ArcView Spatial Analyst and the hazard susceptibility condition of the different classes of the different triggering factors are computed as shown in Table 6.

Table 4: Weight values of the factor classes.

\begin{tabular}{|c|c|c|c|c|c|c|c|}
\hline Factor & Classes & $\begin{array}{l}(\%) \\
\text { percen } \\
\text { tage of } \\
\text { covera } \\
\text { ge }\end{array}$ & $\begin{array}{l}\text { Ranks } \\
\text { (Ri),\% }\end{array}$ & Factors & Classes & $\begin{array}{c}(\%) \\
\text { percenta } \\
\text { ge of } \\
\text { coverage }\end{array}$ & $\begin{array}{c}\text { Ranks( } \\
\text { Ri),\% }\end{array}$ \\
\hline \multirow{4}{*}{ Slope } & $0-15$ & 17 & \multirow[b]{3}{*}{27} & Landuse & $\begin{array}{c}\text { Cultivatio } \\
\mathrm{n}\end{array}$ & 47 & \\
\hline & $15-30$ & 9 & & & Forest & 46 & \\
\hline & $\begin{array}{l}30-45 \\
45-60\end{array}$ & $\begin{array}{l}62 \\
11\end{array}$ & & & $\begin{array}{l}\text { Grass } \\
\text { Land }\end{array}$ & 3 & 8 \\
\hline & $>60$ & 1 & & & $\begin{array}{l}\text { Bush } \\
\text { Land }\end{array}$ & 3 & \\
\hline
\end{tabular}




\begin{tabular}{|c|c|c|c|c|c|c|c|}
\hline & Flat & - & & & $\begin{array}{l}\text { River } \\
\text { Bank }\end{array}$ & 1 & \\
\hline \multirow{8}{*}{ Aspect } & North & & & & $\begin{array}{c}\text { Barren } \\
\text { Land }\end{array}$ & - & \\
\hline & Northeast & 9 & & & & & \\
\hline & East & 19 & 24 & $\begin{array}{c}\text { Drainage } \\
\text { Density }\end{array}$ & High & 25 & \\
\hline & Southeast & 41 & & & Medium & 36 & 7 \\
\hline & South & 29 & & & Low & 39 & \\
\hline & Southwest & 2 & & & & & \\
\hline & West & & & & $0-10$ & 38 & \\
\hline & $750-1300$ & 23 & & & $10-20$ & 23 & \\
\hline \multirow[t]{6}{*}{$\begin{array}{c}\text { Topogra } \\
\text { phical } \\
\text { Height }\end{array}$} & $1300-1700$ & 27 & & $\begin{array}{c}\text { Existing } \\
\text { Landslid } \\
\quad \text { es }\end{array}$ & $20-30$ & 17 & 8 \\
\hline & $1700-2200$ & 24 & 11 & & $30-40$ & 7 & \\
\hline & & & & & $40-50$ & 5 & \\
\hline & $2200-2700$ & 26 & & & $>50$ & 10 & \\
\hline & & & & & $5-10$ & 22 & \\
\hline & & & & $\begin{array}{l}\text { Distance } \\
\text { from } \\
\text { streams }\end{array}$ & $10-15$ & 20 & \\
\hline \multirow[t]{3}{*}{ Soil Type } & $\begin{array}{c}\text { Humic } \\
\text { Cambisols } \\
(\mathrm{CMu})\end{array}$ & 30 & & & $15-20$ & 15 & 8 \\
\hline & $\begin{array}{c}\text { Eutric } \\
\text { Regosols } \\
\text { (RGe) }\end{array}$ & 60 & 11 & & $20-25$ & 9 & \\
\hline & $\begin{array}{c}\text { Eutric } \\
\text { cambisiols } \\
(\mathrm{CMe})\end{array}$ & 10 & & & $>25$ & 34 & \\
\hline
\end{tabular}

\section{Result and Discussion}

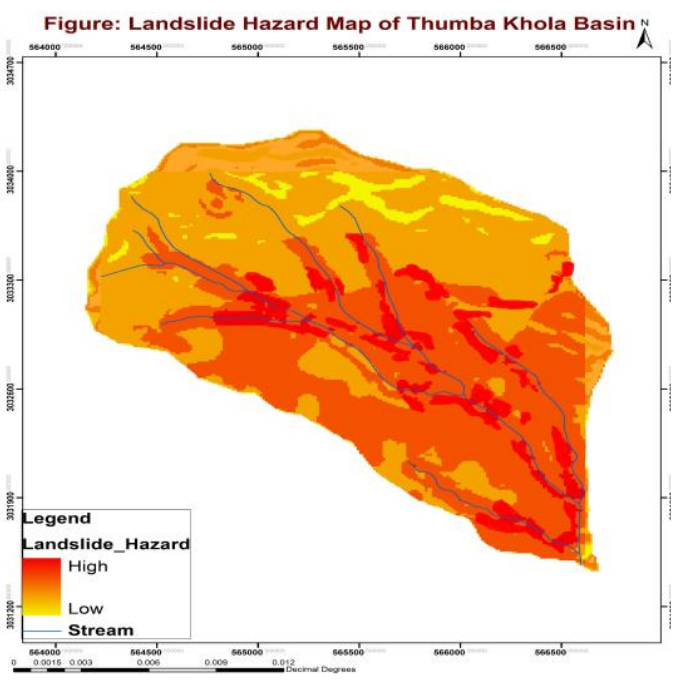

Figure 8: Landslide Hazard Map
Hazard Zonation; The factors susceptible to landslides are set on higher percentages. Similarly, criteria that have lower influence to landslide are set for lower percentage value. After the weightage factors, several landslide susceptible zones were classified into three relative hazard classes' i.e. High, Medium and Low by equal interval classification method.About $70 \%$ hazard coverage within the study basin is in High risk, $11.3 \%$ in medium and $18.7 \%$ in Low risk.

The histogram function shows highest distribution of hazard zone with high risk fall within the elevation range of 1700 m- $2200 \mathrm{~m}$ a.sl whereas, hazard zone with medium risk lie within the elevation range of 750-1300 $\mathrm{m}$ a.sl. 
Furthermore, most of the hazard zones are distributed in the area with past landslide. According to the histogram, $63 \%$ of cultivated land and $80 \%$ of forest is south facing whereas, $30 \%$ of agricultural land is north facing. About $60 \%$ of south facing cultivated lands having slope of 45-60 degree is susceptible to landslide.

\section{CONCLUSION AND RECOMMENDATION}

There has been a gradual increase in the landslide disaster events since last two decades, which has become more pronounced in the last decade. The landslide ultimately contributes to mass deposit in downhill rivers add sediments to rivers and also have significant influence on human life and properties. Since, GIS is helpful tool to analyse hazard but in addition, inputs through AHP returns. Recommendations by weighting various evaluation criteria according to the objectives, as well as the alternatives from the viewpoint of each evaluation criterion and the final scores of the alternatives.

Therefore, in case of Thumba Basin, risk predicated should be scrutinised. Early warning System, planning and prioritizing disaster mitigation efforts should be timely build to address the forthcoming complications.

\section{ACKNOWLEDGEMENT}

I would like to include special note of thanks to Sr. Engineer Mr.Anil Kutuwo for guidance and expertise and also Sanima Hydro team for the assistance.

\section{REFERENCES}

a) Bhatt, Bharat Prashad, et al. (2013) "Using geographic information system and analytical hierarchy process in landslide hazard zonation."sunkkoshi Applied Ecology and Environmental Sciences $1.2: 14-22$.

b) Clerici, Aldo, et al. (2006)"A GIS-based automated procedure for landslide susceptibility mapping by the conditional analysis method: the Baganza valley case study (Italian Northern Apennines)." Environmental Geology 50.7: 941-961.

c) Hasegawa S.,et al..(2009). "Drainage density as rainfall-induced landslides susceptibility index." International journal of Landslide and Environment 1.1 (2014):Nepal 27-28

d) "Major tropical soils and their susceptibility to land degradation", 2017 Retrieved from (www.fao.org,) FAO classification (1974 Soil Map of the World edition)

e) Morton, Steven R.(2000) "Factors influencing shear strength and slope failures in basalt soils of north eastern New South Wales." ISRM International Symposium. International Society for Rock Mechanics,.

f) Pareta, Kuldeep, and Upasana Pareta.(2012): "Landslide modeling and susceptibility mapping of Giri river watershed, Himachal Pradesh (India)." International Journal of Science and Technology 1.2 91-104.

g) Pathak, Dinesh. (2014)"Water Induced Disaster in Tamor River Sub-Basin, East Nepal." DWIDP Bulletin, Series XV: 6-11.

h) Reneau, Steven L., and William E. Dietrich.1980 "The importance of hollows in debris flow studies; examples from Marin County, California." Reviews in engineering geology 7 (1987): 165-180.

i) Saaty T.L., The analytical hierarchy process, McGraw Hill, New York,.

j) Sakunda Ojha and, Sobit Thapaliya (2015)'Landslide Hazard Zonation of Sunkoshi -2 Hydropower Project area using Quantitative methods in GIS. ”ASET

k) Survey Department, His Majesty's Government of Nepal (1993) Topographic maps of Nepal. Produced in cooperation with the FINNIDA. 1996

1) Yalcin, A. (2008). GIS-based landslide susceptibility mapping using analytical hierarchy process and bivariate statistics in Ardesen (Turkey): comparisons of results and confirmations. Catena, 72(1), 1-12. 